ISSN 1392-3196 / e-ISSN 2335-8947

Zemdirbyste-Agriculture, vol. 103, No. 2 (2016), p. 123-128

DOI 10.13080/z-a.2016.103. 016

\title{
Response of soil physical properties and dehydrogenase activity to contrasting tillage systems
}

\author{
Edvin NUGIS, Liina EDESI, Kalvi TAMM, Jüri KADAJA, Elina AKK, \\ Peeter VIIL, Ene ILUMÄE \\ Estonian Crop Research Institute \\ J. Aamisepa 1, 48309, Jõgeva, Estonia \\ E-mail: edvin.nugis@etki.ee
}

\begin{abstract}
The aim of this study was to compare the influence of conventional tillage (CT) and no tillage (NT) on sandy loam and loamy sand soils in three sites of Estonia: 1) Viljandi county (Gleic Albeluvisol), 2) Valga county (FragiStagnic Albeluvisol) and 3) Pärnu county (Mollic Gleysol). The dry bulk density, gravimetric water content and dehydrogenase activity of the soils were determined in the spring of 2013 and 2014. In addition, a soil density index based on soil dry bulk density differences was introduced. Soil samples were collected from 0-10 and $10-20 \mathrm{~cm}$ layers in spring.

The no tillage treatment had higher soil dry bulk density than the conventional tillage in Gleic Albeluvisol and Mollic Gleysol, where the no tillage fields had not been ploughed for 10 and 2 years, correspondingly. The index of soil density varied between $0.289-0.511$, when compared the no tillage and conventional tillage treatments the lowest values were obtained in Gleic Albeluvisol and Mollic Gleysol. Gravimetric water content was significantly lower $2-5 \%(p<0.05)$ in the conventional than in no tillage treatments. No tillage fields showed higher soil dehydrogenase activity in the upper $0-10 \mathrm{~cm}$ layer, conventional tillage treatments had no significant differences between the layers. Soil dehydrogenase activity had significant positive correlation $(p<0.01)$ with soil gravimetric water content and organic carbon, and negative correlation $(p<0.05)$ with soil dry bulk density and soil density index.
\end{abstract}

Key words: conventional tillage, dry bulk density, gravimetric water content, no tillage, soil density index, soil microbial activity.

\section{Introduction}

In order to facilitate plant growth, it is important to create favourable conditions in the soil for root development. The major factor influencing soil structure and thereby soil air-water content, as well as the movement and availability of plant nutrients, is soil tillage. The adoption of no tillage farming systems has globally an increasing trend (Derpsch et al., 2010) because they require less energy and machinery inputs (Triplett, Dick, 2008) and reduce wind and water erosion (Verhulst et al., 2010). In addition, no tillage has been found to improve soil quality by improving soil structure, water holding capacity and water infiltration due to lesser physical disruption of soil aggregates (Verhulst et al., 2010). In contrast to no tillage management, conventional tillage, with ploughing, may result in increasing soil erosion and loss of soil structure (Kassam et al., 2009). Also, the no tillage may have some disadvantages. In northern Europe, due to the higher soil water content, the soils under no tillage tend to warm slowly (Mikkola et al., 2005). Higher bulk density in no tillage than in conventional tillage was found on a sandy loam soil in
Denmark by Munkholm et al. (2003) already in the first year after conversion. However, Vogeler et al. (2009) suggest that 6 years after conversion to no tillage, the differences equalize or bulk density of no tillage is even less than that after ploughing.

Also, different soil tillage practices influence the soil processes which are carried out by microorganisms through the changes of plant residue distribution and soil physical properties (Bogužas et al., 2010; Janušauskaitė et al., 2013). Soil enzymatic activity is a sensitive indicator of tillage management induced changes in soil microorganisms (Watts et al., 2010). Dehydrogenase is an enzyme that occurs in all viable microbial cells and therefore soil dehydrogenase activity is the most adequate and widely used bioindicator (Wolinska, Stepniewska, 2012).

The aim of this study was to evaluate the effect of conventional and no tillage practices on soil bulk density, gravimetric water content, soil density index and microbial activity in sandy loam and loamy sand soils in three Estonian regions. 


\section{Materials and methods}

Experimental sites. The field experiment was carried out in 2012-2014 in the commercial fields in Estonia. The trial plots were located on three different farmers' fields. Site 1 was located in Abja-Paluoja, South part of Viljandi county (58 $\left.7^{\circ} 39^{\prime \prime} \mathrm{N}, 25^{\circ} 15^{\prime} 32^{\prime \prime} \mathrm{E}\right)$, site 2 - in Oru, Valga county (57 $56^{\prime} 31^{\prime \prime}$ N, 26 $6^{\circ} 9^{\prime} 17^{\prime \prime}$ E) and site
3 - in Halinga, Pärnu county $\left(58^{\circ} 38^{\prime} 18^{\prime \prime} \mathrm{N}, 24^{\circ} 21^{\prime} 17^{\prime \prime}\right.$ E). The soils were classified according to the WRB (2014). The fields were selected on the principle that in all three sites the comparison pairs of conventional (CT) and no tillage (NT) fields locate closely (under similar weather conditions) and have similar soil characteristics (Table 1).

Table 1. Classification and characteristics of the experimental soils

\begin{tabular}{|c|c|c|c|c|c|c|c|c|c|c|c|c|}
\hline \multirow{3}{*}{$\begin{array}{l}\text { Loca- } \\
\text { tion }\end{array}$} & \multirow{3}{*}{$\begin{array}{c}\text { Soil } \\
\text { classification } \\
(\mathrm{WRB})\end{array}$} & \multirow{3}{*}{$\begin{array}{l}\text { Depth } \\
\mathrm{cm}\end{array}$} & \multicolumn{5}{|c|}{ Notillage } & \multicolumn{5}{|c|}{ Conventional tillage } \\
\hline & & & \multirow[b]{2}{*}{$\mathrm{C}_{\text {org }}$} & \multicolumn{3}{|c|}{ soil fraction $\%$} & \multirow[b]{2}{*}{$\begin{array}{l}\text { Soil texture } \\
\text { (FAO) }\end{array}$} & \multirow[b]{2}{*}{$\mathrm{C}_{\text {org }}$} & \multicolumn{3}{|c|}{ soil fraction $\%$} & \multirow[b]{2}{*}{$\begin{array}{c}\text { Soil texture } \\
\text { (FAO) }\end{array}$} \\
\hline & & & & $\begin{array}{c}\text { sand } \\
>0.063\end{array}$ & $\begin{array}{c}\text { silt } \\
0.002-0.063\end{array}$ & $\begin{array}{c}\text { clay } \\
<0.002\end{array}$ & & & $\begin{array}{c}\text { sand } \\
>0.063\end{array}$ & $\begin{array}{c}\text { silt } \\
0.002-0.063\end{array}$ & $\begin{array}{c}\text { clay } \\
<0.002\end{array}$ & \\
\hline \multirow{2}{*}{ Site 1} & \multirow{2}{*}{$\begin{array}{c}\text { Gleic } \\
\text { Albeluvisol }\end{array}$} & $0-10$ & 1.6 & 59.5 & 31.5 & 9.0 & sandy loam & 1.5 & 66.4 & 27.1 & 6.5 & \\
\hline & & $10-20$ & 1.4 & 59.6 & 32.7 & 7.7 & sandy loam & 1.4 & 77.3 & 19.1 & 3.6 & loamy sand \\
\hline \multirow{2}{*}{ Site 2} & \multirow{2}{*}{$\begin{array}{c}\text { Fragi-Stagnic } \\
\text { Albeluvisol }\end{array}$} & $0-10$ & 1.4 & 69.3 & 22.5 & 8.3 & sandy loam & 1.5 & 83.5 & 12.5 & 4.0 & loamy sand \\
\hline & & $10-20$ & 1.6 & 66.1 & 27.2 & 6.8 & sandy loam & 1.5 & 74.7 & 19.7 & 5.6 & sandy loam \\
\hline \multirow{2}{*}{ Site 3} & \multirow{2}{*}{ Mollic Gleysol } & $0-10$ & 4.0 & 66.6 & 23.4 & 10.0 & sandy loam & 3.1 & 68.5 & 22.5 & 9.0 & sandy loam \\
\hline & & $10-20$ & 3.1 & 71.0 & 19.7 & 9.3 & sandy loam & 2.8 & 71.3 & 20.6 & 8.1 & sandy loam \\
\hline
\end{tabular}

Notes. Organic carbon $\left(\mathrm{C}_{\text {org }}\right)$ content in soils was measured by NIRS method. For soil texture determination the sieving method was used.

Crops grown in the years of observation are presented in Table 2. Unfortunately, in Fragi-Stagnic
Albeluvisol the farmers continued the crop rotation differently in 2014.

Table 2. Cultivated crops in no tillage (NT) and conventional tillage (CT) fields in 2013-2014

\begin{tabular}{|c|c|c|c|}
\hline Soil & Treatment & 2013 & 2014 \\
\hline \multirow{2}{*}{ Gleic Albeluvisol } & NT & winter wheat & spring barley \\
\hline & $\mathrm{CT}$ & winter wheat & spring barley \\
\hline \multirow{2}{*}{ Fragi-Stagnic Albeluvisol } & NT & oats & winter wheat \\
\hline & $\mathrm{CT}$ & oats & spring rape \\
\hline \multirow{2}{*}{ Mollic Gleysol } & NT & spring barley & spring rape \\
\hline & CT & spring barley & spring rape \\
\hline
\end{tabular}

Experimental design. Tillage systems in the CT fields were mouldboard ploughing with a depth of $20 \mathrm{~cm}$. The NT fields in Gleic Albeluvisol and FragiStagnic Albeluvisol had not been ploughed for ten years and in Mollic Gleysol for the last two years. From each observed field a represntive study area with size 1 ha was selected and the soil physical parameters were measured at three fixed points, in total six measurements per two years. Each measurement point was established by GPS equipment.

Soil dry bulk density (DBD) and gravimetric water content (GWC). In the spring of 2013 and 2014 the soil dry bulk density $\left(\mathrm{Mg} \mathrm{m}^{-3}\right)$ and soil gravimetric water content $\left(\mathrm{kg} \mathrm{kg}^{-1}\right)$ were measured in the depths of 3-8 and $13-18 \mathrm{~cm}$ to give evaluation for layers $0-10$ and $10-20 \mathrm{~cm}$. The DBD was determined by Eijekelkmp's cylinder (100 $\pm 0.14 \mathrm{~cm}^{3}$ with $50.0 \mathrm{~mm}$ internal diameter and $50.8 \mathrm{~mm}$ height). The soil samples were oven-dried at $105^{\circ} \mathrm{C}$ for $24 \mathrm{~h}$ and re-weighed for determination of GWC.

Soil density index (SDI). Range of soil dry bulk density interval is different for different soils. The same DBD value may affect crop growth variously in different soils. Therefore, to compare density of different soils, introducing an index considering available limits of density range is rational. The same approuch has been also used by several authors (Mouazen, Ramon, 2009; Mueller et al., 2009). The main principle of assessment of such kind limited system is to calculate the relation between the difference of the most loosened and particular intermediate states, and the difference of the most loosened and compacted states. Resulting from this principle the SDI can be presented on the basis of void ratio values.

$$
S D I=\frac{\varepsilon_{o}-\varepsilon_{i}}{\varepsilon_{o}-\varepsilon_{\min }}
$$

where $\varepsilon_{o}$ and $\varepsilon_{\min }$ are void ratios of soil in the most loosened and compacted states, respectively; $\varepsilon_{i}$ is void ratio of particularly observed ploughed or no tillage soil.

In our research the determined parameter is dry bulk desity. Therefore, using the definition of void ratio:

$$
\varepsilon=\frac{\delta-\gamma}{\gamma}
$$

where $\delta$ is specific density (density of dry solid material) and $\gamma$ is dry bulk density of soil, we substituted (2) to the eq. 1 and after transformation the SDI is calculable as:

$$
S D I=\left(1-\frac{\gamma_{o}}{\gamma_{i}}\right) /\left(1-\frac{\gamma_{o}}{\gamma_{\max }}\right)
$$


where $\gamma_{o}$ is dry bulk density of soil in its most loosened state, $\gamma_{i}$ - current value of observed soil dry bulk density in ploughed or no-tillage treatment, $\gamma_{\max }-$ limit of dry bulk density of soil in the state of maximum compaction, at which plants are not able to grow any more.

Soil dehydrogenase activity (DHA). Soil samples were taken in the spring of 2013 and 2014, before cultivation, from each treatment in six replications (three in each year) by a random method from the $0-10$ and $10-20 \mathrm{~cm}$ soil layers with a $1 \mathrm{~cm}$ diameter auger. Each soil sample was composite of 20 subsamples. Samples were sieved $(2 \mathrm{~mm})$ and kept at $4^{\circ} \mathrm{C}$ until analysis. DHA was measured in $5 \mathrm{~g}$ soil samples incubated at $30^{\circ} \mathrm{C}$ for $24 \mathrm{~h}$ in the presence of an alternative electron acceptor triphenyltetrazoliumchloride. The red-tinted product triphenylformazan (TPF) was extracted with acetone and measured in a spectrophotometer at $546 \mathrm{~nm}$.

Statistical analysis. All results were based on six soil sample replicates. The data were analyzed by ANOVA. The Tukey-Kramer honest significant sifference (HSD) test and correlation matrix were used via the software JMP 5.0.1.2 (SAS, 2002).

\section{Results and discussion}

Soil physical properties. The soil DBD is usually the most important parameter to describe the soil physical status. The moderate DBD $\left(1.3-1.5 \mathrm{Mg} \mathrm{m}^{-3}\right)$ enhances root growth and thus increases the crop yield (Tracy et al., 2012). At the same time for crop growth, the optimal and critical limits of DBD depend on soil texture, particle shape, and the content of organic matter, which affect soil structure and, thus mechanical resistance of the soil (Guimarães et al., 2002). In this study the average for all years, sites and depths were similar for the both tillage systems: NT -1.48 and $\mathrm{CT}-1.47 \mathrm{Mg} \mathrm{m}^{-3}$ (Table 3). As well, within one treatment significant differences between DBD in 0-10 and 10-20 cm soil layers did not occur. The highest DBD in both investigated soil layers was measured in Fragi-Stagnic Albeluvisol with the high sand and low silt and clay content (Table 1) being higher in the CT treatment: $0-10 \mathrm{~cm}-1.69$ and $10-20 \mathrm{~cm}-$ $1.70 \mathrm{Mg} \mathrm{m}^{-3}$ (Table 3).

Dexter (2004) indicated that the critical bulk density in sandy loam was $1.7 \mathrm{Mg} \mathrm{m}^{-3}$ and therefore according to this value in the Fragi-Stagnic Albeluvisol in CT treatment the critical value of DBD was almost reached. The tendency of higher bulk density in NT than CT treatment was observed in Gleic Albeluvisol and Mollic Gleysol, where the NT treatment fields had not been ploughed for ten and two years, accordingly. Higher soil DBD in sandy loam in no till than ploughed soil was found by Munkholm et al. (2003) too, already within the first year after conversion to NT.

Table 3. Mean values of soil dry bulk density (DBD), gravimetric water content (GWC), soil density index (SDI) and soil dehydrogenase activity (DHA) in no tillage (NT) and conventional tillage (CT) fields during 2013-2014

\begin{tabular}{|c|c|c|c|c|c|c|c|c|c|}
\hline \multirow[t]{2}{*}{ Soil } & \multirow{2}{*}{$\begin{array}{c}\text { Depth } \\
\mathrm{cm}\end{array}$} & \multicolumn{2}{|c|}{$\begin{array}{c}\text { DBD } \\
\mathrm{Mg} \mathrm{m}^{-3}\end{array}$} & \multicolumn{2}{|c|}{$\begin{array}{l}\text { GWC } \\
\mathrm{kg} \mathrm{kg}^{-1}\end{array}$} & \multicolumn{2}{|c|}{ SDI } & \multicolumn{2}{|c|}{$\begin{array}{c}\text { DHA } \\
\text { TPF } \mu \mathrm{g}^{-1} \mathrm{~g}^{-1} \mathrm{~h}^{-1}\end{array}$} \\
\hline & & NT & $\mathrm{CT}$ & NT & $\mathrm{CT}$ & NT & $\mathrm{CT}$ & NT & $\mathrm{CT}$ \\
\hline \multirow{2}{*}{ Gleic Albeluvisol } & $0-10$ & $1.45 \mathrm{bc}$ & $1.35 \mathrm{~cd}$ & $0.249 \mathrm{bc}$ & $0.217 \mathrm{~b}$ & $0.395 \mathrm{~cd}$ & $0.312 \mathrm{~d}$ & $4.21 \mathrm{c}$ & $2.79 \mathrm{~d}$ \\
\hline & $10-20$ & $1.46 \mathrm{bc}$ & $1.36 \mathrm{~cd}$ & $0.226 \mathrm{bcd}$ & $0.213 \mathrm{~b}$ & $0.400 \mathrm{~cd}$ & $0.332 \mathrm{~d}$ & $1.81 \mathrm{e}$ & $2.27 \mathrm{de}$ \\
\hline \multirow{2}{*}{ Fragi-Stagnic Albeluvisol } & $0-10$ & $1.60 \mathrm{ab}$ & $1.69 \mathrm{a}$ & $0.210 \mathrm{de}$ & $0.156 \mathrm{fg}$ & $0.467 \mathrm{bc}$ & $0.509 \mathrm{ab}$ & $3.89 \mathrm{~cd}$ & $2.50 \mathrm{~d}$ \\
\hline & $10-20$ & $1.59 \mathrm{ab}$ & $1.70 \mathrm{a}$ & 0.195 ef & $0.149 \mathrm{~g}$ & $0.462 \mathrm{bc}$ & $0.511 \mathrm{a}$ & $2.63 \mathrm{~d}$ & $2.26 \mathrm{de}$ \\
\hline \multirow{2}{*}{ Mollic Gleysol } & $0-10$ & $1.35 \mathrm{~cd}$ & $1.29 \mathrm{~d}$ & $0.280 \mathrm{a}$ & $0.259 \mathrm{~b}$ & $0.329 \mathrm{~d}$ & $0.289 \mathrm{~d}$ & $12.05 \mathrm{a}$ & $11.19 \mathrm{ab}$ \\
\hline & $10-20$ & $1.44 \mathrm{bcd}$ & $1.40 \mathrm{~cd}$ & $0.282 \mathrm{a}$ & $0.263 \mathrm{~b}$ & $0.388 \mathrm{~cd}$ & $0.359 \mathrm{~d}$ & $9.68 \mathrm{~b}$ & $10.61 \mathrm{ab}$ \\
\hline$p>F$ & & \multicolumn{2}{|c|}{$<0.001$} & \multicolumn{2}{|c|}{$<0.001$} & \multicolumn{2}{|c|}{$<0.001$} & \multicolumn{2}{|c|}{$<0.001$} \\
\hline
\end{tabular}

Notes. Different letters after the mean values indicate significant differences $(p<0.05)$ in a category. Significances of model effects $(p>F)$ are indicated. In the case of significant model effects, a Tukey-Kramer HSD test was performed in order to compare mean values. The red-tinted product triphenylformazan (TPF) was used as DHA indicator.

During 2013-2014 the average soil GWC for all treatments, depths and years was $0.249 \mathrm{~kg} \mathrm{~kg}^{-1}$ (Table 3). Considerably lower GWC, averaged over different sites, was measured in $\mathrm{CT}$ treatments compared to NT fields, where the average GWC was $2.0-5.0 \%$ higher in $0-20 \mathrm{~cm}$ soil layer. Higher soil moisture content in NT treatments was probably due to the fact that in spring the soil surface was covered with plant residue, which reduced access of solar radiation and hindered the soil evaporation. In turn, this effect may cause serious delay in the drilling of spring-sown crops (Soane et al., 2012). This is a common problem in northern Europe (Van den Putte et al., 2010). Drilling may be delayed there up to a week compared to drilling into ploughed soils, and therefore, may decrease the yield (Mikkola et al., 2005), although in semi-arid areas, as south-western Europe, the residues in soil surface have been found to conserve the soil and water as well as increase the yield (Van den Putte et al., 2010).

In addition, our results indicate, that GWC was the highest $\left(0.280-0.282 \mathrm{~kg} \mathrm{~kg}^{-1}\right)$ in Mollic Gleysol in NT field (Table 3), where the organic carbon content was the highest (3.1-4.0\%) (Table 1). The strong positive relationship between soil moisture and organic carbon has been also documented by Manns and Berg (2014).

The SDI varied between $0.289-0.511$ (Table 3). The favourable level of SDI is below 0.33 (Materechera, 2009; Agbede, 2010; Mellek et al, 2010). In our 
investigations this condition was met in CT fields of Gleic Albeluvisol and Mollic Gleysol (Table 3). Similary to DBD, the highest SDI values were found in the fields of Fragi-Stagnic Albeluvisol being in both treatments higher than favourable, and indicating unfavorable soil physical condition for plant growth there (Table 3). Also, SDI was considerably higher in CT than NT treatment in this site. The contrast in DBD and SDI results between FragiStagnic Albeluvisol and Gleic Albeluvisol and Mollic Gleysol is mostly associated with the different crops. In Fragi-Stagnic Albeluvisol in the second experimental year, the winter wheat was grown in NT treatment, but the spring rape in CT field (Table 2). Suppousedly, a reason here is different soil texture in different experimental sites, too: high soil sand content in Fragi-Stagnic Albeluvisol.

Soil dehydrogenase activity (DHA). The study results in NT systems showed the higher DHA in the upper 0-10 cm soil layer than in 10-20 cm layer (Table 3), similar results were found by Gajda et al. (2013). The higher microbial activity in upper layer of no till soils is associated with higher organic carbon in this layer. In CT treatments, no significant difference in DHA between soil layers was observed. Similar results were found by Janušauskaitė et al. (2013). Higher upper layer DHA in NT than CT fields in Gleic Albeluvisol and Mollic Gleysol was probably related to significantly higher soil GWC, and in addition for Fragi-Stagnic Albeluvisol to the lower sand content compared to CT treatment (Tables 1-3). The strong positive relationship between DHA and GWC is also demonstrated by the correlation $(P<0.01, r=0.71)$ (Table 4) and has been obtained by other researchers as well (Zhang et al., 2015). The negative relationship between sand content and soil microorganisms was also observed by Najmadeen et al. (2010).

Table 4. Correlation coefficents $(r)$ of soil dehydrogenase activity (DHA) with soils physical properties and organic carbon $\left(\mathrm{C}_{\text {org }}\right)$ in all investigated fields at a soil depth of $0-20 \mathrm{~cm}(\mathrm{n}=72)$

\begin{tabular}{ccccc}
\hline & GWC g kg-1 & DBD Mg m${ }^{-3}$ & SDI & $\mathrm{C}_{\text {org }}$ \\
\hline DHA $\left(\right.$ TPF $\left.\mu \mathrm{g}^{-1} \mathrm{~g}^{-1} \mathrm{~h}^{-1}\right)$ & $0.71^{* *}$ & $-0.47^{*}$ & $-0.42^{*}$ & $0.94^{* *}$ \\
\hline
\end{tabular}

Note. The red-tinted product triphenylformazan (TPF) was used as DHA indicator; GWC - gravimetric water content, DBD - dry bulk density, SDI - soil density index; ${ }^{*}-P<0.05$ and $* * P<0.01$.

No significant difference in soil dehydrogenase activity was found between NT and CT treatments in Mollic Gleysol, which may be due to implementation of no till technology for a short period (Table 3). Although the sand content of soil was high in Mollic Gleysol, compared to other test areas, the organic carbon content of these soils was higher (Table 1). Most microorganisms are chemoorganotrophic, because they use organic carbon as a source of carbon and energy. Therefore, the higher organic carbon levels have been found to support greater enzyme activities in soils (Niemeyer et al., 2012; Gajda et al., 2013). Also, in this study the correlation between the content of organic carbon and soil DHA was strong $(P<0.01, r=0.94)$ (Table 4$)$. An increase in the DBD and SDI had a negative influence on soil DHA $(P<0.05$, $r=-0.47$ and $r=-0.42$ ) (Table 4). Gispert et al. (2013) also found the most abundant soil microbial populations in the low bulk density treatments, presumably due to the favourable soil physical conditions.

\section{Conclusions}

1. The no tillage system raised soil water content, but at the same time increased the soil dry bulk density.

2. The soil density index suggests a better soil physical condition in conventionally tilled fields.

3. Study results in no tillage systems showed the higher soil dehydrogenase activity in the upper $0-10 \mathrm{~cm}$ soil layer than in the $10-20 \mathrm{~cm}$ layer. In conventional tillage treatments, no significant difference in soil dehydrogenase activity between both soil layers was observed.

4. The positive correlations of soil dehydrogenase activity with soil gravimetric water content and organic carbon, and negative correlation with soil dry bulk density and soil density index confirmed its strong dependence on the cultivation methods, which in turn influenced the soil physical parameters.

\section{Acknowledgements} of Agriculture.

This work was funded by the Estonian Ministry

Received 13102015

Accepted 26022016

\section{References}

Agbede T. M. 2010. Tillage and fertilizer effect on some soil properties, leaf nutrient concentrations, growth and sweet potato yield on an Alfisol in southwestern Nigeria. Soil and Tillage Research, 110: 25-32 http://dx.doi.org/10.1016/j.still.2010.06.003

Bogužas V., Kairytė A., Jodaugienė D. 2010. Soil physical properties and earthworms as affected by soil tillage systems, straw and green manure management. Zemdirbyste-Agriculture, 97 (3): 3-14

Derpsch R., Friedrich T., Kassam A., Hongwen L. 2010. Current status of adoption of no-till farming in the world and some of its main benefits. International Journal of Agricultural and Biological Engineering, 3: 1-25

Dexter A. R. 2004. Soil physical quality. Part I. Theory, effects of soil texture, density, and organic matter, and effects on root growth. Geoderma, 120: 201-214

http://dx.doi.org/10.1016/j.geoderma.2003.09.004

Gajda A. M., Przewłoka B., Gawryjołek K. 2013. Changes in soil quality associated with tillage system applied. International Agrophysics, 27: 133-141 http://dx.doi.org/10.2478/v10247-012-0078-7 
Gispert M., Emran M., Pardini G., Doni S., Ceccanti B. 2013. The impact of land management and abandonment on soil enzymatic activity, glomalin content and aggregate stability. Geoderma, 202-203: 51-61 http://dx.doi.org/10.1016/j.geoderma.2013.03.012

Guimarães C. M., Stone L. F., Moreira J. A. A. 2002. Soil compaction in a bean crop. II. Effect on root and shoot development. Revista Brasileira de Engenharia Agrícola e Ambiental, 6: 213-218 http://dx.doi.org/10.1590/S1415-43662002000200005

Janušauskaitè D., Kadžienè G., Auškalnienė O. 2013. The effect of tillage system on soil microbiota in relation to soil structure. Polish Journal of Environmental Studies, 22 (5): 1387-1391

Kassam A. H., Friedrich T., Shaxson F., Pretty J. 2009. The spread of conservation agriculture: justification, sustainability and uptake. International Journal of Agricultural Sustainability, 7 (4): $1-29$

http://dx.doi.org/10.3763/ijas.2009.0477

Manns H. R., Berg A. A. 2014. Importance of soil organic carbon on surface soil water content variability among agricultural fields. Journal of Hydrology, 516: 297-303 http://dx.doi.org/10.1016/j.jhydrol.2013.11.018

Materechera S. A. 2009. Tillage and tractor traffic effects on soil compaction in horticultural fields used for periurban agriculture in a semi-arid environment of the North West Province, South Africa. Soil and Tillage Research, 103: $11-15$

http://dx.doi.org/10.1016/j.still.2008.09.001

Mellek J. E., Dieckow J., da Silva V. L., Favaretto N., Pauletti V., Vezzani F. M., de Souza J. L. M. 2010. Dairy liquid manure and no-tillage: Physical and hydraulic properties and carbon stocks in Cambisol of Southern Brazil. Soil and Tillage Research, 110: 69-76 http://dx.doi.org/10.1016/j.still.2010.06.005

Mikkola H. J., Alakukku L., Känkänen H., Jalli H., Lindroos M., Huusela-Veistola E., Nuutinen V., Lätti M., Puustinen M., Turtola E., Myllys M., Regina K. 2005. Direct drilling in Finland, a review. Proceedings of $4^{\text {th }}$ international scientific and practical conference Ecology and Agricultural Machinery. St. Petersburg, Russia, 2: 141-151

Mouazen A. M., Ramon H. 2009. Expanding implementation of an on-line measurement system of topsoil compaction in loamy sand, loam, silt loam and silt soils. Soil and Tillage Research, 103: 98-104 http://dx.doi.org/10.1016/j.still.2008.09.012

Mueller L., Kay B. D., Chunsheng H., Li Y., Schindler U., Behrendt A., Sheperd T. G., Ball B. C. 2009. Visual assessment of soil structure: evaluation of methodologies on sites in Canada, China and Germany. Part I. Comparing visual methods and linking them with soil physical data and grain yield of cereals. Soil and Tillage Research, 103: $178-187$ http://dx.doi.org/10.1016/j.still.2008.12.015

Munkholm L. J., Schjonning P., Rasmussen K. J., Tanderup K. 2003. Spatial and temporal effects of direct drilling on soil structure in the seedling environment. Soil and Tillage Research, 71: 163-173 http://dx.doi.org/10.1016/S0167-1987(03)00062-X

Najmadeen H. H., Mohammad A. O., Mohamed-Amin H. H. 2010. Effects of soil texture on chemical compositions, microbial populations and carbon mineralization in soil. The Egyptian Journal for Experimental Biology, 6 (1): 59-64
Niemeyer J. C., Lolatac G. B., de Carvalhod G. M., Da Silva E. M., Sousa J. P., Nogueirac M. A. 2012. Microbial indicators of soil health as tools for ecological risk assessment of a metal contaminated site in Brazil. Applied Soil Ecology, 59: 96-105

SAS 2002. JMP, statistics and graphics guide, version 5. SAS Institute, Cary, USA http://dx.doi.org/10.1016/j.apsoil.2012.03.019

Soane B. D., Ball B. C., Arvidsson J., Basch G., Moreno F., Roger-Estrade J. 2012. No-till in northern, western and south-western Europe: a review of problems and opportunities for crop production and the environment. Soil and Tillage Research, 118: 66-87 http://dx.doi.org/10.1016/j.still.2011.10.015

Tracy S. R., Black C. R., Roberts J. A., McNeill A., Davidson R., Tester M., Samec M., Korosak D., Sturrock C., Mooney S. J. 2012. Quantifying the effect of soil compaction on three varieties of wheat (Triticum aestivum $\mathrm{L}$.) using x-ray micro computed tomography (CT). Plant and Soil, 353: 195-208 http://dx.doi.org/10.1007/s11104-011-1022-5

Triplett G. B. Jr., Dick W. A. 2008. No-tillage crop production: a revolution in agriculture. Agronomy Journal, 100: $153-165$ http://dx.doi.org/10.2134/agronj2007.0005c

Van den Putte A., Govers G., Diels J., Gillijns K., Demuzere M. 2010. Assessing the effect of soil tillage on crop growth. A meta-regression analysis on European crop yields under conservation agriculture. European Journal of Agronomy, 33: $231-241$ http://dx.doi.org/10.1016/j.eja.2010.05.008

Verhulst N., Govaerts B., Verachtert E., CastellanosNavarrete A., Mezzalama M.,Wall P., Deckers J., Sayre K. D. 2010. Conservation agriculture, improving soil quality for sustainable production systems? Lal R., Stewart B. A. (eds.). Advances in soil science: food security and soil quality. Boca Raton, USA, p. 137-208

Vogeler I., Rogasik J., Funder U., Panten K., Schnug E. 2009. Effect of tillage systems and P-fertilization on soil physical and chemical properties, crop yield and nutrient uptake. Soil and Tillage Research, 103: 137-143 http://dx.doi.org/10.1016/j.still.2008.10.004

Watts D. B., Torbert H. A., Feng Y., Prior S. A. 2010. Soil microbial community dynamics as influenced by composted dairy manure, soil properties, and landscape position. Soil Science, 175: 474-486 http://dx.doi.org/10.1097/SS.0b013e3181f7964f'

Wolinska A., Stepniewska Z. 2012. Dehydrogenase activity in the soil environment. Canuto R. A. (ed.). Dehydrogenases, section 3, chapter 8. Rijeka, Croatia http://dx.doi.org/10.5772/48294

WRB. 2014. World reference base for soil resources 2014 . World Soil Resources Reports. FAO, 191 p.

Zhang N., Wan S., Guo J., Han G., Gutknecht J. B., Yu L., Liu W., Bi J., Wang Z., Ma K. 2015. Precipitation modifies the effects of warming and nitrogen addition on soil microbial communities in northern Chinese grasslands. Soil Biology and Biochemistry, 89: 12-23 http://dx.doi.org/10.1016/j.soilbio.2015.06.022 
ISSN 1392-3196 / e-ISSN 2335-8947

Zemdirbyste-Agriculture, vol. 103, No. 2 (2016), p. 123-128

DOI 10.13080/z-a.2016.103. 016

\title{
Dirvožemio fizikinès savybės ir dehidrogenazės aktyvumas taikant ịvairias žemès dirbimo sistemas
}

\author{
E. Nugis, L. Edesi, K. Tamm, J. Kadaja, E. Akk, P. Viil, E. Ilumäe \\ Estijos augalininkystès tyrimų institutas
}

\section{Santrauka}

Tyrimo tikslas - palyginti tradicinị ir nearimini žemės dirbimą smèlingo priemolio bei rišlaus smèlio dirvožemiuose trijose Estijos vietovèse: 1) Viljandeje (Gleic Albeluvisol), 2) Valgoje (Fragi-Stagnic Albeluvisol) ir 3) Pernu (Mollic Gleysol) apylinkèse. Dirvožemio tankis, gravimetrinė drègmè ir dehidrogenazės aktyvumas buvo nustatyti 2013 ir 2014 m. pavasarị. Be to, buvo ịvestas dirvožemio tankio indeksas, paremtas skirtumais tarp dirvožemio tankių. Ėminiai buvo paimti pavasarị iš dirvožemio 0-10 ir 10-20 cm sluoksnių.

Neariminio žemès dirbimo variante buvo nustatytas didesnis dirvožemio tankis, palyginus su tradiciniu dirbimu Gleic Albeluvisol ir Mollic Gleysol, kur neariminio varianto laukai nebuvo arti atitinkamai 10 ir 2 metus. Dirvožemio tankio indeksas ịvairavo nuo 0,289 iki 0,511 , palyginus neariminio ir tradicinio žemės dirbimo variantais, mažiausios vertès buvo nustatytos ariamų variantų Gleic Albeluvisol ir Mollic Gleysol tyrimų vietovèse. Gravimetrinès drėgmès kiekis buvo žymiai mažesnis $(2-5 \%, p<0.05)$ žemę dirbant tradiciškai nei neariminio žemès dirbimo variantuose. Neariminio žemès dirbimo variantuose didesnis dehidrogenazès aktyvumas buvo nustatytas dirvožemio viršutiniame $0-10 \mathrm{~cm}$ sluoksnyje, o tradicinio žemès dirbimo variantuose esminių skirtumų tarp sluoksnių nebuvo nustatyta. Dirvožemio dehidrogenazès aktyvumas esmingai teigiamai $(p<0,01)$ koreliavo su dirvožemio gravitacinès drègmès ir organinès anglies kiekiu ir neigiamai $(p<0,05)$ - su dirvožemio tankiu ir tankio indeksu.

Reikšminiai žodžiai: dirvožemio mikrobų aktyvumas, dirvožemio tankis, dirvožemio tankio indeksas, gravimetrinès drègmès kiekis, neariminis žemès dirbimas, tradicinis žemès dirbimas.

Please use the following format when citing the article:

E. Nugis, L. Edesi, K. Tamm, J. Kadaja, E. Akk, P. Viil, E. Ilumae. 2016. Response of soil physical properties and dehydrogenase activity to contrasting tillage systems. Zemdirbyste-Agriculture, 103 (2): 123-128 DOI 10.13080/z-a.2016.103.016 